\title{
Botrytis Fruit Rot or Gray Mold of Strawberry ${ }^{1}$
}

\author{
J. C. Mertely, M. S. Oliveira, and N. A. Peres
}

Botrytis fruit rot (BFR), also known as gray mold, is caused by the fungus Botrytis cinerea and is one of the most important diseases of strawberry in Florida and worldwide. The fungus infects all aerial parts of the plant; however, most economic damage occurs when flowers and fruit are affected, occasionally resulting in yield losses greater than $50 \%$. BFR is also a post-harvest disease, because infections that begin in the field continue to develop during storage and transit at refrigeration temperatures. Weather conditions favorable to disease development are $63^{\circ} \mathrm{F}$ to $77^{\circ} \mathrm{F}$ and prolonged leaf wetness, and are often encountered in Florida during the strawberry production period from November to March.

\section{Symptoms}

Strawberry flowers are highly susceptible to $B$. cinerea, and may be blighted directly. However, symptoms are usually observed 2 to 4 weeks after infection, on green and ripening fruit. Lesions typically develop under the calyx as small, light brown spots (Figures 1 and 2) that enlarge quickly and invade the rest of the fruit (Figure 3). Lesions become fully covered with dark mycelium bearing many gray spores (conidia) (Figure 4). Large numbers of spores are released as visible gray puffs when infected fruit are disturbed. Eventually, the fruit becomes totally covered and mummified (Figure 5).

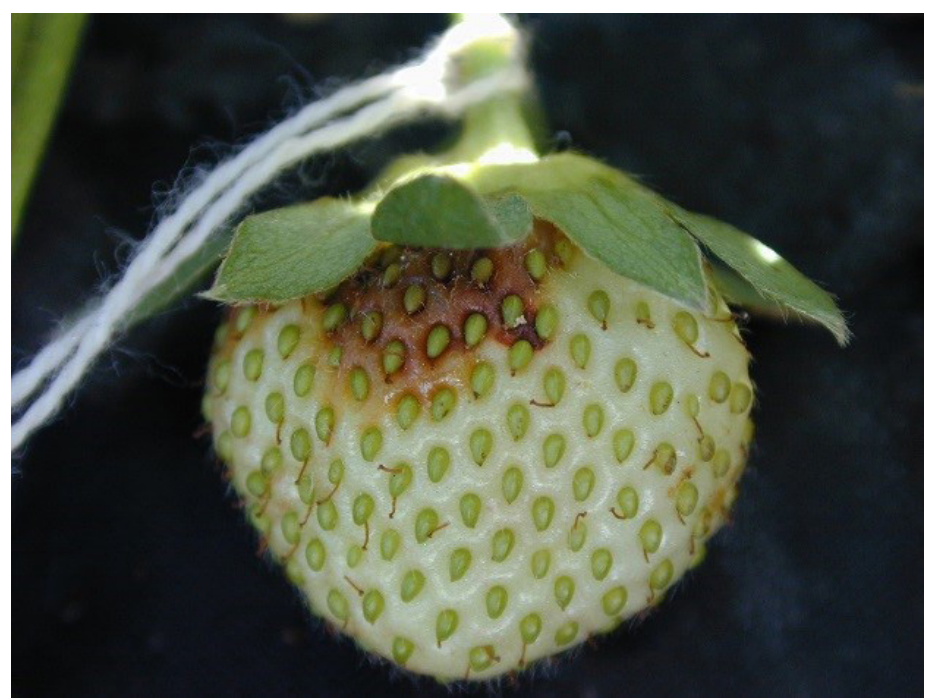

Figure 1. BFR lesion starting under the strawberry calyx. Credits: James Mertely, UF/IFAS

\section{Disease Development and Spread}

B. cinerea can survive in soils as sclerotia or mycelium. However, due to high temperatures during the Florida summer, the pathogen is not able to survive and is commonly introduced into production fields through infected transplants. Foliage from nursery transplants are a known source of $B$. cinerea inoculum. After transplanting, old, infected leaves gradually die, becoming a source of inoculum (spores) responsible for infection of emerging

1. This document is PP230, one of a series of the Plant Pathology Department, UF/IFAS Extension. Original publication date July 2006. Revised February 2018. Visit the EDIS website at http://edis.ifas.ufl.edu.

2. J. C. Mertely, biological scientist IV; M. S. Oliveira, graduate student; and N. A. Peres, professor; UF/IFAS Gulf Coast Research and Education Center, Wimauma, FL 33598.

The use of trade names in this publication is solely for the purpose of providing specific information. UF/IFAS does not guarantee or warranty the products named, and references to them in this publication does not signify our approval to the exclusion of other products of suitable composition. Recommendations given in this fact sheet are based on experimentation and statements from the manufacturer. Consult the product label for specific use requirements and restrictions.

The Institute of Food and Agricultural Sciences (IFAS) is an Equal Opportunity Institution authorized to provide research, educational information and other services only to individuals and institutions that function with non-discrimination with respect to race, creed, color, religion, age, disability, sex, sexual orientation, marital status, national origin, political opinions or affiliations. For more information on obtaining other UF/IFAS Extension publications, contact your county's UF/IFAS Extension office. 
leaves and flowers. B. cinerea is a polycyclic pathogen that continuously produces inoculum throughout the season. The spores are dispersed by air, water splash, harvesters' hands, and direct contact with infected stems and fruit (Figure 6). A combination of weather conditions conducive for disease $\left(63^{\circ} \mathrm{F}\right.$ to $77^{\circ} \mathrm{F}$ and at least 13 hours of continuous leaf wetness), presence of the pathogen, and presence of susceptible tissue (flowers and fruit) will result in disease development. As an epidemic progresses, diseased fruit, mummified fruit, and decayed flowers and pedicels become important new sources of inoculum. Consequently, BFR is usually more severe during the late season fruiting period in February and March.

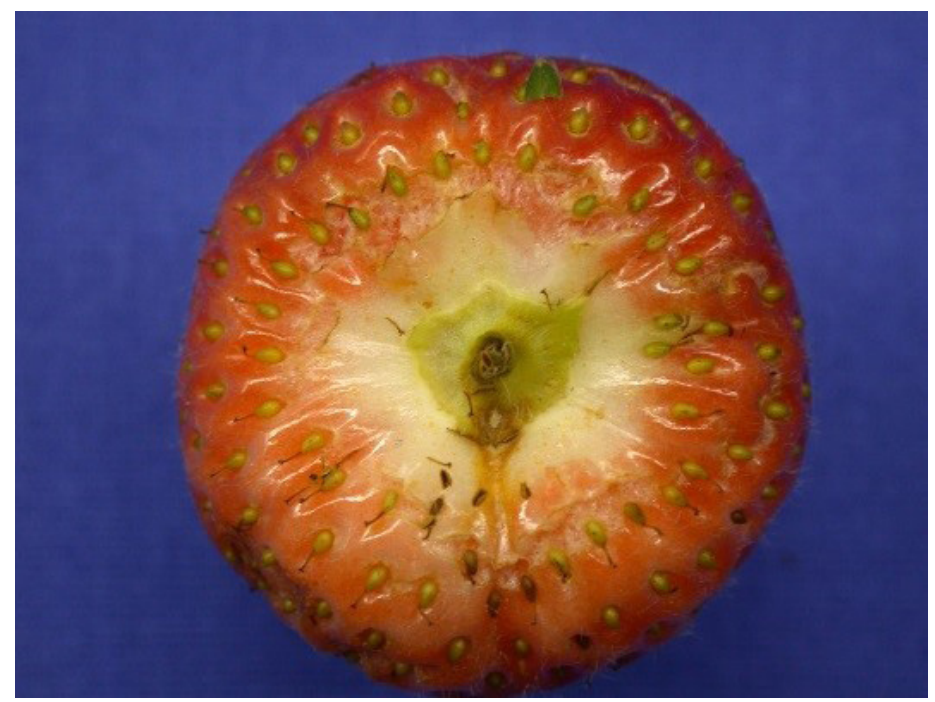

Figure 2. BFR lesion starting from the strawberry calyx (top view). Credits: James Mertely, UF/IFAS

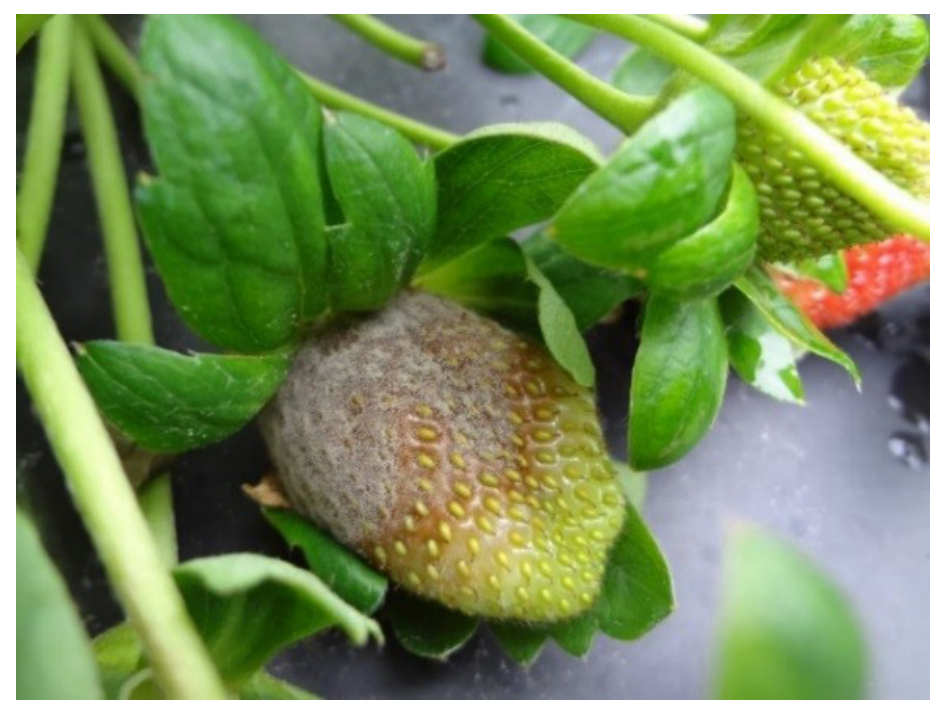

Figure 3. Infection of B. cinerea on green strawberry fruit. Credits: Michelle S. Oliveira, UF/IFAS

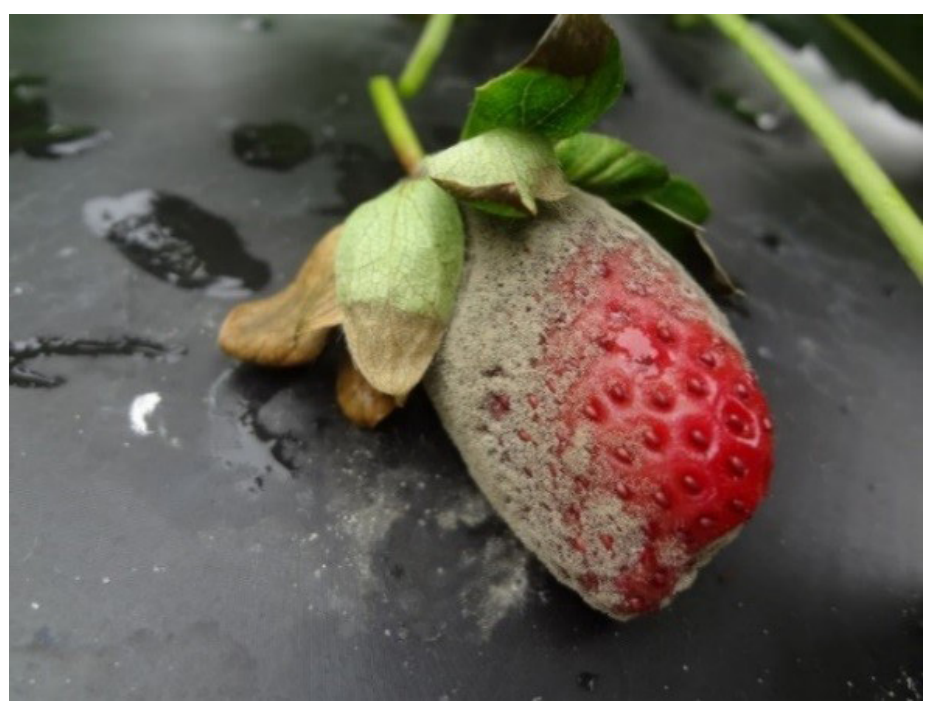

Figure 4. Colonization and sporulation of $B$. cinerea on strawberry fruit. Credits: Michelle S. Oliveira, UF/IFAS

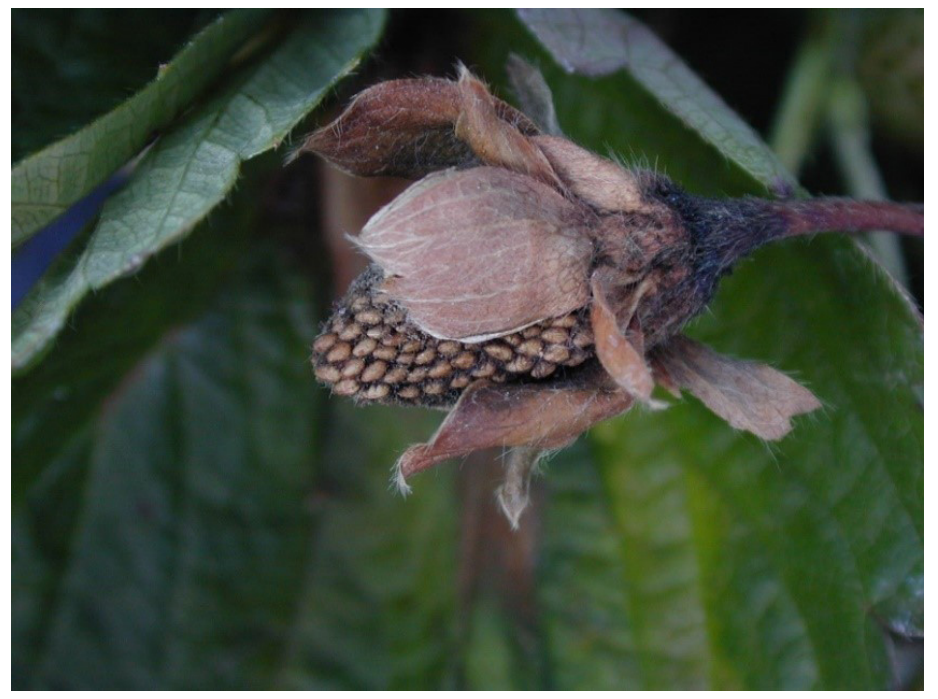

Figure 5. Mummified strawberry fruit after colonization with BFR. Credits: UF/IFAS

\section{BFR Management}

BFR should be managed by cultural and chemical methods. There are no commercial cultivars highly resistant to this disease. Removal of diseased fruit from under the plant canopy reduces inoculum and, consequently, infection efficiency and disease spread by fruit-to-fruit contact. Leaf pruning, on the other hand, only modestly reduces disease incidence, and usually does not increase marketable yield. Yields may even be reduced by pruning if partially green leaves are also removed.

Therefore, growers primarily rely on fungicide sprays for management of BFR. An initial fungicide dip treatment of the plants is often used to manage other pathogens, such as the anthracnose fungus Colletotrichum acutatum, but studies have shown that they are not effective for BFR management. Traditional spray programs consisted of 
calendar sprays at regular intervals. Protectant fungicides such as Captan and Thiram were applied when flowers were sparse and weather unfavorable, whereas single-site botryticides (Elevate, Kenja, Luna, Switch, etc.) were applied during bloom periods when weather conditions favored the disease. This management method involved up to 22 applications per season, and many of these may have been unnecessary.

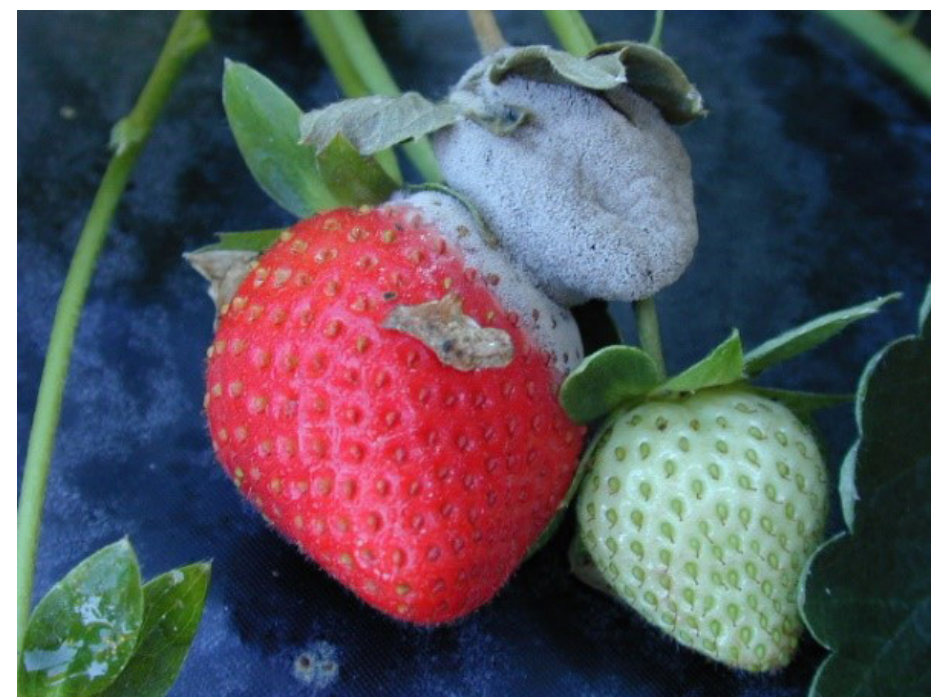

Figure 6. Fruit-to-fruit spread of B. cinerea.

Credits: UF/IFAS

An alternative to calendar-based sprays became available with the release of the Strawberry Advisory System (StAS) in 2009 (http://agroclimate.org/tools/sas/fl/). The StAS is a weather-based decision support system that forecasts the risk of anthracnose fruit rot and BFR incidence based on leaf wetness duration and temperature during the wetting period. The system advises growers on the timing of fungicide application, as well as which fungicide should be sprayed depending on the risk of infection and crop phenology. Experiments carried out on several commercial fields in Florida showed that the system, on average, reduces the number of fungicide sprays by about $50 \%$ without affecting disease incidence or yield compared to weekly sprays. Fungicides used to manage BFR in Florida are listed in Table 1.

Studies have shown that B. cinerea populations are currently resistant to fungicides from multiple chemical groups. Even populations from nursery transplants have shown multi-fungicide resistance (MFR) to two to six fungicides. Management strategies that aim to extend the life of effective fungicides include: i) alternating fungicides with different modes of action, ii) tank mixtures of singlesite and multi-site fungicides, and iii) restrictions on the maximum number of applications for any given product or mode of action. Many of these strategies are incorporated into the recommendations from the StAS. 
Table 1. Fungicides recommended for control of Botrytis fruit rot of strawberries in Florida.

\begin{tabular}{|c|c|c|c|c|c|}
\hline \multirow[t]{2}{*}{$\begin{array}{l}\text { Product name (active } \\
\text { ingredient) }\end{array}$} & \multirow[t]{2}{*}{$\begin{array}{l}\text { Fungicide } \\
\text { Group }^{a}\end{array}$} & \multicolumn{2}{|c|}{$\begin{array}{l}\text { Maximum Rate Per } \\
\text { Acre Per }\end{array}$} & \multirow[t]{2}{*}{$\begin{array}{l}\text { Min. Days } \\
\text { to Harvest }\end{array}$} & \multirow[t]{2}{*}{ Remarks } \\
\hline & & Application & Season & & \\
\hline $\begin{array}{l}\text { Thiram Granuflo, Thiram } \\
\text { 24/7 (thiram) }\end{array}$ & M2 & \multicolumn{3}{|c|}{ See individual labels } & $\begin{array}{l}\text { Do not rotate treated crops with other crops for which } \\
\text { Thiram is not registered. }\end{array}$ \\
\hline Captan 80 WDG (captan) & M4 & $3.75 \mathrm{lb}$ & $30 \mathrm{lb}$ & 1 & Rate per treated acre. \\
\hline $\begin{array}{l}\text { Captevate } 68 \text { WDG } \\
\text { (captan }+ \text { fenhexamid) }\end{array}$ & M4 + 17 & $5.25 \mathrm{lb}$ & $21 \mathrm{lb}$ & 0 & Do not make more than 2 consecutive applications. \\
\hline Fontelis (penthiopyrad) & 7 & $24 \mathrm{fl} \mathrm{oz}$ & $72 \mathrm{fl} \mathrm{oz}$ & 0 & $\begin{array}{l}\text { Do not make more than } 2 \text { sequential applications before } \\
\text { alternating to a fungicide from a different group. }\end{array}$ \\
\hline $\begin{array}{l}\text { Kenja } 400 \text { SC } \\
\text { (isofetamid) }\end{array}$ & 7 & $15.5 \mathrm{fl} \mathrm{oz}$ & $54 \mathrm{fl} \mathrm{oz}$ & 1 & $\begin{array}{l}\text { Do not plant other crops not registered for } 30 \text { days after } \\
\text { last application. }\end{array}$ \\
\hline $\begin{array}{l}\text { Elevate } 50 \text { WDG } \\
\text { (fenhexamid) }\end{array}$ & 17 & $1.5 \mathrm{lb}$ & $6 \mathrm{lb}$ & 0 & Do not make more than 2 consecutive applications. \\
\hline $\begin{array}{l}\text { Merivon (fluxapyroxad + } \\
\text { pyraclostrobin) }\end{array}$ & $7+11$ & $11 \mathrm{floz}$ & $33 \mathrm{floz}$ & 0 & $\begin{array}{l}\text { Do not make more than } 2 \text { sequential applications before } \\
\text { alternating to another non-Group } 7 \text { or non-Group } 11 \\
\text { fungicide. }\end{array}$ \\
\hline $\begin{array}{l}\text { Luna Tranquility } \\
\text { (fluopyram + } \\
\text { pyrimethanil) }\end{array}$ & $7+9$ & $27 \mathrm{fl} \mathrm{oz}$ & $54.7 \mathrm{fl} \mathrm{oz}$ & 1 & $\begin{array}{l}\text { Do not make more than } 2 \text { sequential applications before } \\
\text { rotating with a fungicide from a different group. }\end{array}$ \\
\hline $\begin{array}{l}\text { Switch } 62.5 \text { WG } \\
\text { (cyprodinil + fludioxonil) }\end{array}$ & $9+12$ & $14 \mathrm{oz}$ & $56 \mathrm{oz}$ & 0 & $\begin{array}{l}\text { Do not make more than } 2 \text { consecutive applications. Do } \\
\text { not plant crops not on the label for } 30 \text { days after last } \\
\text { application. }\end{array}$ \\
\hline \multicolumn{6}{|c|}{$\begin{array}{l}\text { a Fungicide group (FRAC Code): Numbers (1-37) and letters }(M) \text { are used to distinguish the fungicide mode of action groups. All fungicides } \\
\text { within the same group (with the same numbers or letter) indicate same active ingredient or similar mode of action. This information must be } \\
\text { considered for the fungicide resistance management decisions. } M=\text { Multi-site inhibitors, fungicide resistance risk low. Source: FRAC Code List } \\
\text { 2017; (FRAC = Fungicide Resistance Action Committee). }\end{array}$} \\
\hline
\end{tabular}

